\title{
Czym jest Zagłada dla historyka?
}

\author{
Bogumił Rudawski (Uniwersytet im. Adama Mickiewicza, Poznań)
}

W niniejszym artykule chciałbym ukazać wieloraką perspektywę historycznych badań nad Zagładą, wybrałem trzy jej aspekty: dynamikę znaczeniową pojęcia ludobójstwa, historyzację Zagłady, a także badania nad pośmiertnymi losami ciała ludzkiego na terenie obozu zagłady.

\section{Ludobójstwo}

Oczywisty jest dla nas dzisiaj fakt, że Zagłada jest przykładem ludobójstwa. Anihilacja narodu żydowskiego w Europie podczas II wojny światowej stała się impulsem do zdefiniowania zjawiska ludobójstwa i wprowadzenia go do prawa międzynarodowego. Twórcą pojęcia „ludobójstwo” był Rafał Lemkin, Polak żydowskiego pochodzenia. Poprzez stworzony przez siebie neologizm "genocide" rozumiał on zniszczenie narodu lub grupy etnicznej. Ten neologizm zrodził się z powiązania dwóch terminów, jednego o źródłosłowie greckim: genos (rasa, plemię), drugiego zaś o źródłosłowie łacińskim: occidere (zabijanie). Autor zaproponował też inną wersję nazwy na określenie zbrodni ludobójstwa, która jednak się nie przyjęła-był to termin „ethnocide” (etnocyd), złożony z greckiego ethnos i łacińskiego occidere (Lemkin 2013 [1944], 110). Znaczenia odsłaniane przez te złożenia stały się punktem wyjścia dla dalszych rozważań, pozwalających np. ujmować ludobójstwo w kategoriach skoordynowanego planu obejmującego sekwencję rozmaitych działań, które miały za zadanie doprowadzić do wyniszczenia danej grupy etnicznej. Lemkin wyróżnił dwie podstawowe fazy zbrodni ludobójstwa: pierwsza faza oznaczała stopniowe, zorganizowane unicestwianie narodowych wzorów życia danej grupy etnicznej; celem drugiej fazy było $\mathrm{z}$ kolei narzucenie danej grupie etnicznej wzorów i sposobów życia opresora (ibid.).

Tak zarysowane, podstawowe założenie ludobójstwa było bezpośrednim skutkiem zinstytucjonalizowanej, antyżydowskiej polityki III Rzeszy, eskalującej w czasie i przybierającej ostatecznie charakter explicite zbrodniczy. W ideologii narodowosocjalistycznej to właśnie naród, stanowiący biologiczny fundament państwowości, stał się główną przesłanką definicji państwa. Definicja ta przekładała się na uzasadnienie dla podejmowania działań wojennych i na ich charakter: były one, jak trafnie zauważył Lemkin, wymierzone nie tyle przeciwko siłom danego państwa, ile przeciwko określonym narodom bądź „rasom”. Wszelkie tak zdefiniowane grupy, uznane 
za niebezpieczne lub wrogie, musiały znaleźć się pod kontrolą okupanta. W ten sposób naród niemiecki zyskiwał przewagę biologiczną, a wraz z nią przewagę polityczną i kulturową. Należało zatem stworzyć odpowiedni system okupacyjny, pozwalający wprowadzić wszechobecną kontrolę podbijanych narodów, a także unicestwić jego zasoby biologiczne czy to w postaci indywidualnych przedstawicieli „ethnosu”, czy to w postaci całej grupy narodowej (ibid. 12). W okresie II wojny światowej grupą narodową, którą postanowiono unicestwić całkowicie- $w$ rozumieniu biologicznym, politycznym i kulturowym-byli Żydzi. Oprócz nich celem eksterminacji ze strony nazistowskiej polityki stały się inne narody; w ich przypadku ograniczono się niekiedy do masowego mordowania niektórych warstw społecznych (Rotfeld 2010, 20-21).

Pojęciem „ludobójstwo" Lemkin objął początkowo dość szeroką skalę działań, stosując to pojęcie praktycznie na wszystkie aspekty działania niemieckiego okupanta na terenie Europy. Wyszczególnił osiem technik ludobójstwa, wśród których znalazły się m.in. techniki społeczne, polityczne, kulturowe, biologiczne, fizyczne i ekonomiczne. Posługując się coraz bardziej precyzyjnymi kategoriami, opisywał za ich pomocą akty ustawodawstwa III Rzeszy i codzienne praktyki wojenno-okupacyjne, zmierzające do unicestwienia podbitych narodów. Za istotną technikę genocydologiczną uznał on ludobójstwo natury „moralnej”, polegające na tym, że „okupant stara się stworzyć atmosferę moralnego upodlenia”, a jednocześnie usiłuje odwrócić uwagę członków danego narodu od refleksji moralnej i dążności do rozwoju moralnego (Lemkin 2013, 113-120). Szerokozakresowa definicja Lemkina, obejmująca skądinąd znane już ludzkości sposoby działania, była jego odpowiedzią jako prawnika i dysydenta na bezwzględny i wszechobecny terror nazistowski. Definiując wieloaspektowo zjawisko eksterminacji narodów, Lemkin stworzył ramy prawne pozwalające należycie ująć zbrodniczy wymiar ludobójstwa, a przede wszystkim warunki proceduralne, mające umożliwiać pociąganie sprawców zbrodni do odpowiedzialności karnej. Lemkin zabiegał o wprowadzenie kategorii ludobójstwa do prawa międzynarodowego i uniwersalizację jurysdykcji międzynarodowej, która nie pozwalałaby żadnemu przestępcy wojennemu uniknąć odpowiedzialności karnej. Już w latach 30-tych (podczas słynnej konferencji w Madrycie) usiłował przeforsować na forum międzynarodowym dwie nowe kategorie zbrodni, określone przezeń jako „barbarzyństwo”" i „wandalizm”, a mające doprowadzić do objęcia penalizacją wszystkich czynów, jakich intencją było wyniszczenie ludzkości (Lemkin 2013, 122). Zbrodnie narodowego socjalizmu stały się koronnym argumentem dla jego starań o przywrócenie idei całościowego ujęcia zbrodni przeciwko ludzkości właśnie jako zbrodni ludobójstwa.

Zagłada postawiła kwestię uznania ludobójstwa za zbrodnię w zupełnie nowym świetle. Pierwszą okazją do zaprezentowania koncepcji ludobójstwa 
miały być dla Lemkina obrady Międzynarodowego Trybunału w Norymberdze. Jednakże nie udało się wówczas włączyć kategorii ludobójstwa do prawa międzynarodowego; termin ten nie pojawił się ani razu w akcie oskarżenia, mimo, że akt ewidentnie dotyczył zbrodni przeciwko ludzkości. Niezrażony porażką Lemkin zaangażował się $\mathrm{z}$ całych sił $\mathrm{w}$ prace nowo utworzonego Zgromadzenia Ogólnego Narodów Zjednoczonych. Już podczas jego pierwszej sesji czynił zabiegi o przyjęcie rezolucji uznającej ludobójstwo za zbrodnię międzynarodową. 11 grudnia 1946 r. odnośna rezolucja została jednomyślnie przyjęta na forum ONZ. Stała się ona podstawą do uchwalenia przez Zgromadzenie Ogólne ONZ dwa lata później, tj. 9 grudnia 1948 r., Konwencji ws. zapobiegania i karania zbrodni ludobójstwa. Był to niekwestionowany sukces Rafała Lemkina. „Konwencja Lemkinowska”, jak zaczęto ją wkrótce nazywać, miała i ma na celu ochronę grup narodowych, etnicznych, rasowych i religijnych przed rozmaitymi formami polityki eksterminacyjnej. Zgodnie z nią, karze podlegają nie tylko czyny o charakterze ludobójczym, ale także podżeganie do nich i współudział w nich (Kuźniar 2013, 18-21).

Wprowadzenie definicji i kategorii ludobójstwa do prawa międzynarodowego oznaczało również nowy punkt wyjścia dla badań naukowych nad problematyką niekwestionowalnych zbrodni przeciwko ludzkości, w tym Holocaustu i wymordowania ok. półtora miliona Ormian przez Turków w latach 1915-1917; w okresie powojennym za kolejną taką zbrodnię uznana została eksterminacja ok. 800 tysięcy Tutsi w Rwandzie w 1994 r. Te trzy przypadki ludobójstwa spełniają wszelkie kryteria definicyjne zbrodni ludobójstwa w ujęciu Lemkinowskim. Zakładają one zorganizowane i systematyczne dokonanie przez dane państwo masowych mordów na bezbronnych ludziach—członkach grupy wyodrębnionej na podstawie przynależności etniczno-religijnej, oraz dążenie przez owo państwo do całkowitego unicestwienia jakichkolwiek materialnych pozostałości po ofiarach (np. osiedli, miejsc kultu, cmentarzy itd.); mowa tutaj zatem o unicestwieniu całkowitym. Inne zbrodnie wymierzone w bezbronnych ludzi, jak np. celowe wywołanie przez Stalina klęski głodu na Ukrainie, wymordowanie Polaków przez Ukraińców na Wołyniu, mordy dokonane przez czerwonych Khmerów w Kambodży nie odpowiadają obecnie przyjętym przez Konwencję kryteriom ludobójstwa. Mają one natomiast charakter zbrodni o charakterze ludobójczym bądź też są przykładami ludobójstwa o podłożu politycznym (politicide), za którego przykład podaje się ludobójstwo dokonane przez czerwonych Khmerów. Ludobójstwo polityczne oznacza masowy mord na osobach określanych jako wrogowie państwa, na podstawie kryteriów natury politycznej lub społeczno-ekonomicznej (por. Midlarsky 2010, 26-41). 


\section{Historyzacja Holocaustu}

Uznanie Holocaustu za przykład ludobójstwa i zbrodni w świetle prawa międzynarodowego nie poskutkowało natychmiastowym wzrostem zainteresowania wśród historyków ani też podjęciem wzmożonych badań nad tym okresem w dziejach dwudziestowiecznej Europy.

Ewolucja poznawczego, historycznego, prawnego, a także socjologicznego podejścia $\mathrm{w}$ badaniach nad Holocaustem jako zbrodnią ludobójstwa dokonywała się pośród mierzących się z tym doświadczeniem badaczy, a także wśród przedstawicieli władz (w tym: prokuratury i sądownictwa), międzynarodowej publiczności, a przede wszystkim: wśród ocalonych, ich potomnych, i wreszcie bezpośrednich sprawców i współsprawców w tempie powolnym. Przykład takiej ewolucji można prześledzić na przykładzie debat, które przetoczyły się przez powojenne Niemcy. Dotyczyły ona sposobu identyfikacji i szacowania skali zbrodni, definiowania jej kontekstu, podłoża i charakteru, a także sposobu określania sprawstwa i współsprawstwa, wreszcie przyjmowania odpowiedzialności i szacowania jej wymiaru (a także wypierania lub-co następowało stopniowo po upływie kilku dekad od zakończenia II Wojny Światowej i trwa po dzień dzisiejszyprzepracowywania win, cierpienia i strat, pamięci wreszcie). Wszystkie te elementy bywały w różnoraki sposób upolityczniane. Nade wszystko jednak rozpoczął się proces historyzacji Holocaustu.

Przez pierwsze dwie dekady powojnia o Holocauście debatowano i pisano niewiele, a przynajmniej nie był on przedmiotem masowego zainteresowania społecznego i historycznego, pomimo, że już z chwilą upadku III Rzeszy pojawiały się pierwsze apele wzywające do rozliczenia się z przeszłością. Thomas Mann, który po emigracji do Stanów Zjednoczonych stał się najsłynniejszym opozycjonistą oraz krytykiem reżimu hitlerowskiego, nawoływał w audycji radiowej-zaledwie dwa dni po „godzinie, w której smok został zabity; skonał obrzydliwy i chory potwór, zwany narodowym socjalizmem"-do porzucenia raz na zawsze ideologii nazizmu. Miał nadzieję, że „opuszczenie flagi ze swastyką oznaczało rzeczywisty, radykalny i nieodwracalny rozbrat niemieckiego myślenia i odczuwania z nazistowską pseudofilozofią” i „powrót Niemiec do człowieczeństwa” (Mann 2008, 53-54). W rzeczywistości aż do połowy lat sześćdziesiątych w Niemczech unikano publicznych debat i rozrachunków. Przełomem inicjującym proces kształtowania się nowoczesnej pamięci niemieckiej i badań historycznych nad Holocaustem przyniosły dwa procesy: proces jerozolimski Adolfa Eichmanna w latach 1960-1962, jednego z głównych architektów „ostatecznego rozwiązania", proces transmitowany na żywo w niemieckiej telewizji publicznej, oraz frankfurcki proces załogi KZ Auchwitz-Birkenau, przeprowadzony w latach 1963-1965 dzięki wieloletniemu zaangażowaniu prokuratora Fritza Bauera. Obydwa procesy uaktywniły intelektualistów niemieckich gwoli przeprowadzenia publicznej debaty, w której za sprawą 
mediów uczestniczyć mogli obywatele. Sprzyjała temu również medialna oprawa procesów; dla przykładu, w procesie frankfurckim każdy chętny mógł uczestniczyć w roli obserwatora. Według relacji dziennikarza Horsta Krügera, w galeriach dla widzów zasiadali przede wszystkim młodzi Niemcy, bowiem, jak z gorzką ironią zauważył Krüger, ich rodzice i dziadkowie „nie chcą już nic o tym słyszeć. Oni wiedzą i znają już wszystko. Teraz, krótko przed dwunastą, muszą pracować, muszą sprawić, żeby cud gospodarczy nie ustał. Kto ogląda się za siebie, ten już przegrał” (Krüger 2008, 136-153).

Podobne refleksje w swoim głośnym eseju zatytułowanym Nasz Auschwitz wyraził Martin Walser, pisarz niezwykle znaczący w procesie niemieckiego rozliczania się z nazistowską przeszłością. Wskazał on także na wręcz niezdrowe zainteresowanie procesem oprawców $\mathrm{z}$ Auschwitz. Podkreślał, że

znana jest fascynacja, jaką wywierają na ludziach obrazy budzące przerażenie. Auschwitz wydaje się-jako cytat z tekstów grozynabierać takiego właśnie rozgłosu. Leży to $\mathrm{w}$ naszej naturze; żaden człowiek-jak sądzę-nie mógłby być obserwatorem na sali sądowej we Frankfurcie, jeżeli uczucie obrzydzenia nie współgrałoby z fascynacją (Walser 2008, 158).

Obserwacja procesów i krytyczna refleksja nad ich społecznym odbiorem doprowadziła Walsera także do innej, jeszcze bardziej istotnej konstatacji:

Byliśmy tamtemu państwu (Trzeciej Rzeszy) o wiele bliżsi, niż nam się to w konfrontacji z Auschwitz wydaje ... Każdy przyczynił się w jakimś stopniu do Auschwitz. I każdy powinien odnaleźć w sobie tę własną część udziału. Nie musiał być wcale członkiem SS" (ibid.).

Kolejnym ważnym momentem o niezwykle silnym ładunku tożsamościowym dla osób mierzących się $\mathrm{z}$ najnowszą historią Niemiec stał się tzw. Historikerstreit, spór wszczęty przez Ernsta Nolte artykułem opublikowanym 6. czerwca 1986 r. na łamach dziennika „Frankfurter Allgemeine Zeitung”. Nolte postawił w nim następujące i-jak się wkrótce okazało-wysoce kontrowersyjne pytania:

Czy archipelag Gułag nie ma prawa starszeństwa w stosunku do Auschwitz? Czy »morderstwo klasowe» dokonane przez bolszewików nie jest logicznym i taktycznym przeciwnikiem »rasowego morderstwa«, dokonanego przez narodowych socjalistów? (Nolte 2008 [1986], 372-373).

Nolte twierdził, że Hitler nie był oryginalny w wynalezieniu masowego ludobójstwa, przejął jedynie metody znane $\mathrm{w}$ stalinowskim Związku Radzieckim. Oczywiście historyk nie zaprzeczał nazistowskim zbrodniom, tylko porównując je do innych, starał się znaleźć ich racjonalną przyczynę i poddać historycznej analizie. Jak sam wyjaśniał na początku swojego artykułu: 
Przeszłość narodowosocjalistyczna natomiast jakby opierała się temu procesowi słabnięcia i więdnięcia. Więcej, zyskuje coraz większą żywotność i potężnieje ... Staje się istnym postrachem, jest przeszłością, która próbuje zająć miejsce teraźniejszości, bądź wisieć nad nią jak miecz Damoklesa (Nolte 2008, 375).

Po stronie Noltego stanęli inni historycy, starając się rozpoznać i zrozumieć brutalną przeszłość i włączyć ją do dyskursu historiograficznego Niemiec. Wojna rozpętana przez nazistów oznaczała w tym dyskursie jedną z wojen charakteryzujących reżimy totalitarne. Ludobójstwo nazistowskie postawione zostało w tym samym szeregu co inne akty ludobójcze. Perspektywie tej najsilniej sprzeciwił się Jürgen Habermas, publikując na łamach innego opiniotwórczego periodyku, „Die Zeit”, esej wymownie zatytułowany Sposób zacierania winy. Habermas wywodził w nim, że „dialektyka wzajemnego grożenia sobie zagładą" prowadzi do relatywizacji niemieckiej kultury pamięci historycznej. Analizując tezy artykułu innego historyka, Andreasa Hillgrubera, na temat niemieckiej polityki eksterminacyjnej, Habermas wnosił, że Hillgruber przybrał „postawę niezaangażowania pod pretekstem, że chodzi o sprawy mieszczące się na płaszczyźnie ogólnoludzkiej” (Hillgruber 1986). Równie zdecydowanie oponował Habermas przeciwko wizji historii III Rzeszy proponowanej przez Klausa Hildebranda, postulującego rewizję historii okresu nazistowskiego i wpisanie jej w zwykły ciąg wydarzeń historycznych. Odnosząc się ponownie do wspomnianego już Noltego, Habermas wykazywał, iż

Nolte ustrzelił dwa wróble za jednym zamachem: zbrodnie nazistowskie przestają być czymś wyjątkowym, skoro można je przynajmniej uczynić zrozumiałymi w tym sensie, że stanowiły replikę na zagrożenie bolszewickie. ... Równocześnie Auschwitz zostaje sprowadzone do poziomu zwykłej innowacji technicznej i tłumaczy się lękiem przed »Azjatąu, wciąż niebezpiecznym i stojącym u naszych wrót (Habermas 2008, 377-385).

W połowie lat osiemdziesiątych 20 wieku jeszcze inny historyk, Martin Broszat, nawoływał w swoim artykule do „nowej rzeczowości” w podejściu do dziejów Trzeciej Rzeszy. Twierdził, że należy poddać dzieje tego państwa historyzacji i przestać traktować je jako sekwencję szczególnych wydarzeń historycznych. Cały proces historyzacji miał mieć z założenia charakter rewizjonistyczny, afirmujący niektóre elementy nazistowskiego planów społecznych (w tym wypadku chodziło o działalność Niemieckiego Frontu Pracy). Takie podejście do historii mogło być następstwem debaty modernizacyjnej, dopatrującej się-zwłaszcza w działalności społecznej nazistów-pozytywnych tendencji $\mathrm{w}$ rozwoju państwa i społeczeństwa niemieckiego, a także mogło być „następstwem afirmacyjnego nacisku legitymizacyjnego", dążącego z kolei do rehabilitacji reżimu hitlerowskiego (Roth 2000, 535-563). 
Przytoczone wyżej kontrowersje i dyskusje dowodzą, że Holocaust był wydarzeniem bez precedensu, nadzwyczaj obciążającym emocjonalnie i moralnie historyków-w przypadku Historikerstreit w szczególności historyków niemieckich. Rewizjonizm historyczny, mimo częstej obecności w badaniach historycznych, $\mathrm{z}$ całą pewnością nie jest najlepszą strategią. Krytyczna historyzacja Holokaustu, skądinąd jak najbardziej pożądana, wymaga olbrzymiej wiedzy fachowej, a także pewnej wrażliwości moralnej.

\section{Badania Raula Hilberga}

W międzyczasie ukonstytuował się inny model badań nad Zagładą, zawdzięczający wiele Rafałowi Lemkinowi i zwłaszcza Raulowi Hilbergowi [1990], który całe swoje życie poświęcił badaniom nad Zagładą Żydów europejskich. Wyróżnił on trzy podstawowe fazy eksterminacji. Faza pierwsza miała polegać na zdefiniowaniu Żyda jako wroga przez wykonujących władzę nazistów; faza druga-na koncentracji ludności żydowskiej w gettach i obozach. Z kolei faza trzecia oznaczała unicestwienie narodu żydowskiego. Zaproponowany przez Hilberga model badań nad Zagładą z perspektywy administracji i z punktu widzenia oprawcy stał się jedną z najważniejszych współcześnie strategii badawczych w warsztacie historyka. Można jeszcze dodać w tym miejscu, że Hilberg wzorował się w dużej mierze na koncepcjach Lemkina (Panne 2010, 102-104). Inną, jeszcze bardziej rozpowszechnioną strategią historycznych badań nad Holocaustem, pozostaje strategia personalna, czyli recepcja Zagłady dokonywana na podstawie lektury wspomnień pozostawionych przez ofiary i ocalonych.

Hilberg opublikował swoje opus magnum w $1961 \mathrm{r}$. W tym samym roku historyk brytyjski A. J. P. Taylor wydał swoją książkę pt. The Origins of the II World War. Dowodził w niej, że odpowiedzialność za zbrodnie narodowosocjalistyczne ponoszą zarówno Niemcy, jak i inne kraje. Wraz z tymi publikacjami (i, rzecz jasna, zarysowanym wyżej Historikerstreit) w latach osiemdziesiątych zrodziły się dwie inne, równie ważne strategie $\mathrm{w}$ badaniach nad Zagładą. Jedną $\mathrm{z}$ nich wypracowali tzw. intencjonaliści, uważający, że źródłem Holocaustu pozostaje ideologia nazistowska, zaś Hitler od początku nosił się z planem dokonania Zagłady. Z kolei funkcjonaliści twierdzą, że Holocaust był rezultatem wielorakich okoliczności, w tym działalności biurokracji partyjnej i wojskowej¹. Raul Hilberg opowiedział się zdecydowanie po stronie funkcjonalistów. Podział na te dwa „obozy” nadal pozostaje ważnym punktem odniesienia dla badaczy opisujących Zagładę.

Bardzo skrótowo tylko zaglądając do polskiej historiografii poświęconej Holocaustowi można, w przekonaniu autora, wyróżnić trzy najważniejsze nurty. Z jednej strony wielu badaczy eksploruje pewne mechanizmy

${ }^{1}$ http://www.centrum-anielewicza.uw.edu.pl/kolo-relacje-schnepf2.htm 
administracyjne, które miały swój udział w tworzeniu obozów zagłady, a także w samym przebiegu Zagłady w różnych regionach Polski. Innym istotnym, i może nawet bardziej rozpoznawalnym nurtem historiograficznym w Polsce, są relacje świadków historii, generalnie: cała memuarystyka związana $\mathrm{z}$ eksterminacją Żydów. W trzecią, stosunkowo nową tendencję badawczą wpisują się badania nad współudziałem Polaków w nazistowskich zbrodniach popełnionych na Żydach i współodpowiedzialnością za ich dokonywanie. Nurty te nie muszą występować rozłącznie w badaniach prowadzonych przez historyków.

\section{Ludzkie ciało w obozie zagłady i obozie koncentracyjnym. Historyk wobec tematów granicznych}

W ostatniej części opracowania wskażę podstawowe sposoby traktowania zwłok ludzkich w obozach zagłady, przywołując świadectwa pochodzące $\mathrm{z}$ okresu tuż po ich wyzwoleniu. Uczynię to, aby pokazać historyczne strategie obchodzenia się z tak trudną materią na przykładzie relacji pisemnej i nowej narracji historycznej, koncentrującej się na temacie ludzkiego ciała.

Jednym $\mathrm{z}$ najbardziej porażających doświadczeń $\mathrm{w}$ obozach koncentracyjnych był kontakt $\mathrm{z}$ ludzkimi zwłokami. Administrowanie wszechobecną śmiercią i zwłokami wprowadziło do przestrzeni obozowej rytuały i procedury $\mathrm{w}$ najwyższym stopniu odhumanizowane. W drugiej połowie maja 1944 r. do KZ Auschwitz trafił lekarz węgierskiego pochodzenia, Miklós Nyiszli. Przeszedł on pozytywnie selekcję na rampie kolejowej i jako specjalista w zakresie medycyny sądowej został zatrudniony przez doktora Josefa Mengele do przeprowadzania sekcji zwłok bliźniąt i karłów. Pracując na terenie krematorium był bezpośrednim świadkiem śmierci wielu tysięcy ludzi, przede wszystkim swoich rodaków. W spisanych po wojnie wspomnieniach zawarł opis śmierci ludzi $\mathrm{w}$ komorach gazowych—jedno $\mathrm{z}$ najbardziej wstrząsających źródeł i świadectw zagłady Żydów:

Gdy już zakończono tę »kąpiel umarłych «-z jakim bólem i samozaparciem wykonuje Sondrekommando tę pracęrozpoczyna się rozplątywanie góry ciał. Ciężka to praca: zakładając postronki na przeguby zaciśniętych $\mathrm{w}$ pieści dłoni rozrywa się piramidę; wlecze się śliskie, mokre zwłoki do znajdującej się w sąsiedniej sali windy. Pracuje tam wielki dźwig towarowy. Na platformę kładzie się po dwadzieścia-dwadzieścia pięć trupów. Dzwonkiem sygnalizuje się, że winda może ruszyć. Podjeżdża ona w górę, do krematorium - wielkie drzwi rozchylają się automatycznie. ... Zwłoki starych, młodych i dzieci leżą długim rzędem na betonie. $\mathrm{Z}$ nosa, z ust, z pokaleczonych ciał sączy się krew, miesza się z płynącą nieustannie po betonowej podłodze wodą, lejącą się z otwartych kranów. ... Kiedy już ostatni złoty ząb 
został wyrwany, ofiary przechodzą w ręce komanda pracującego przy piecach. ... Ciała spalają się w ciągu dwudziestu minut. W krematorium pracuje piętnaście palenisk. Dzienna przepustowość-pięć tysięcy ludzi. Wszystkie cztery krematoria mają taką samą przepustowość. Dwadzieścia tysięcy ludzi wchodzi codziennie do komór gazowych, a stamtąd trafia do pieców. Dusze tysięcy ludzi ulatują codziennie przez kominy. Nie pozostaje po nich nic więcej, poza kupką popiołu na podwórzu krematorium (Nyiszli 2010, 39-40).

Dla historyka to wstrząsające świadectwo jest $\mathrm{z}$ jednej strony przede wszystkim źródłem historycznym, dotyczącym przebiegu eksterminacji w obozach zagłady Auschwitz i Birkenau, z drugiej strony pozostawia ono historyka początkowo? Bezradnym i przerażonym wobec przeczytanych słów. Nawet jednak takie opisy domagają się krytyki źródłowej i postawienia sobie kilku badawczych pytań. Jedno z pierwszych powinno brzmieć: Kto i w jakich okolicznościach pozostawił taki opis? Jak to możliwe, że osoba, która widziała i doświadczyła tak wiele w obozie zagłady, przeżyła wojnę? Na ile autentyczne są te wspomnienia?

Kiedy oglądamy różne zdjęcia z wyzwolenia obozów koncentracyjnych, widzimy z reguły więźniów tychże obozów lub stosy ludzkich zwłok. Jest to jeden $\mathrm{z}$ najpopularniejszych przekazów wizualnych dotyczących historii eksterminacji Żydów. Z chwilą, gdy Armia Czerwona wyzwoliła obozów Auschwitz i Birkenau, znajdowało się tam ok. siedem tysięcy żywych więźniów i sześć tysięcy martwych ciał. Ciała leżały w różnych częściach obozu, na wewnętrznych drogach, w barakach, a także na drogach dojazdowych do obozu. W większości były zamarznięte, nadpalone, niektóre nadgryzione przez szczury. Osłabieni i wycieńczeni więźniowie nie mieli siły pogrzebać zwłok. Sami potrzebowali natychmiastowej pomocy lekarskiej. Ludzkie szczątki, które wcześniej były utylizowane przez administrację niemiecką, leżały teraz wszędzie. Były codziennością dla żywych i walczących o przeżycie.

Dlatego najważniejszym zadaniem wojsk radzieckich było uporządkowanie terenu obozowego. Pierwszą praktyką $w$ ramach tych działań było porządkowanie ludzkich ciał. Zwłoki ludzkie przenoszono do masowych grobów lub bloków-kostnic. Uruchomiono także dwa radzieckie szpitale polowe oraz szpital utworzony przez oddział Polskiego Czerwonego Krzyża, gdzie udzielano pomocy medycznej więźniom. Istotnym działaniem było porządkowanie i zbieranie dowodów zbrodni niemieckich. Prokuratura radziecka prowadziła szereg badań kryminalistycznych, jak chociażby sekcje zwłok, których głównym celem było ustalenie przyczyn zgonu. Szereg tych praktyk lekarskich i kryminalistycznych spowodowało, że ciało traktowano jako przedmiot i dowód zbrodni, jako corpus delicti. Do dziś ciało ludzkie i stan jego wyniszczenia w warunkach obozowych są ważnym dowodem oskarżenia wobec nazistów. Symbolicznym zakończeniem prac porządkowych w obozie 
był uroczysty, masowy pogrzeb zmarłych więźniów, który odbył się na terenie dawnego obozu 28. lutego 1945 r., w miesiąc po wyzwoleniu obozu. W zbiorowej mogile pochowano czterysta siedemdziesiąt ciał (Zawodna 2012, 145-165).

Przytoczona wyżej relacja Zawodnej z historii ostatnich dni obozu i pierwszych dni wolności nie jest ujęta w klasyczne ramy historiograficzne. Podstawowym punktem odniesienia jest w niej ciało ludzkie. Szczątki ludzkie są głównym nośnikiem opowieści o wydarzeniach, jakie miały miejsce w obozach Auschwitz i Birkenau w styczniu i lutym 1945 r. Siła tej opowieści polega na tym, że odbiorca nie skupia się wyłącznie na faktach, lecz jest z nimi konfrontowany także w sposób emocjonalny i egzystencjalny.

\section{Zakończenie}

Próbując odpowiedzieć na postawione w tytule tego artykułu pytanie badawcze, starałem się zwrócić uwagę na dwie istotne rzeczy: Z jednej strony Zagłada jest tematem badawczy, który podlega regułom metodologicznym dyscypliny naukowej, jaką jest historia; z drugiej natomiast praca badawcza nad Zagładą wymaga nie tylko wiedzy merytorycznej, ale także dużej wrażliwości, która jednak nie powinna przeważać w prowadzonych badaniach. Nie jest to zadanie łatwe. Poprzez prezentację trzech zagadnień teoretycznego ujęcia pojęcia ludobójstwa, omówienie zagadnienia historyzacji Holocaustu i towarzyszących temu kontrowersji-starałem się pokazać złożoność tej problematyki oraz zaproponować pewne ujęcie tematu Zagłady z perspektywy historycznej, uwzględniając nie tylko warsztat metodologiczny historyka, lecz także konteksty otwierane przez inne dyscypliny i debaty.

\section{Literatura}

Bieńczyk-Missala, A. \& Dębski, S. (red.) 2010. Rafał Lemkin. A Hero of Humankind. Warszawa: Polski Instytut Spraw Międzynarodowych.

Engelking, B. 2011. Jest taki piękny słoneczny dzień... Losy Żydów szukająych ratunku na wsi polskiej 1942-1945. Warszawa: Stowarzyszenie Centrum Badań nad Zagładą Żydów.

Hilberg, R. 2008. "Zagłada Żydów europejskich". W Jabłkowska-Żychliński (red.), O kondycji Niemiec..., zob. pełne dane bibliograficzne pod kolejną pozycją. (Oryginalna wersja niemieckojęzyczna: [19901] Die Vernichtung der europäischen Juden. 3 Bände. Frankfurt am Main: Geschichte Fischer Verlag. 
Jabłkowska, J. \& Żychliński, L. (wybór, opracowanie i redakcja) 2008. O kondycji Niemiec. Tożsamość niemiecka $w$ debatach intelektualistów po 1945 roku. Wydawnictwo Poznańskie: Poznań.

Habermas, J. 2008. "Sposób zacierania winy, czyli tendencje apologetyczne we współczesnej historiografii niemieckiej". W Jabłkowska - Żychliński (red.), O kondycji Niemiec..., op. cit.: 377 - 385. (Oryginalna wersja niemieckojęzyczna: [1986] "Eine Art Schadensabwicklung. Die apologetischen Tendenzen in der deutschen Zeitgeschichtschreibung". Die Zeit, 11.07.1986

Hillgruber, A. 1986. Zweierlei Untergang: Die Zerschlagung des Deutschen Reiches und das Ende des europäischen Judentums. München: Siedler Verlag.

Krüger, H. 2008., op. cit. "W labiryncie winy. Jeden dzień z procesu oświęcimskiego". W Jabkowska-Żychliński (red.), o kondycji Niemiec..., op. cit.: 136-153.

Kuźniar, R. 2013. Wprowadzenie. Raphael Lemkin, Rzq̨dy państw Osi w okupowanej Europie. Prawa okupacyjne, analiza rzq̨dzenia, propozycje zadośćuczynienia. Tłum. A. Bieńczyk-Missala, P. Grzebyk, B. Lanckoroński, \& M. Madej. Wydawnictwo Naukowe Scholar: Warszawa: 18-21.

Lemkin, R. 2013. Rzq̨dy państw Osi w okupowanej Europie. Prawa okupacyjne, analiza rzq̨dzenia, propozycje zadośćuczynienia. Tłum. A. BieńczykMissala, P. Grzebyk, B. Lanckoroński, \& M. Madej. Wydawnictwo Naukowe Scholar: Warszawa. Oryginalna wersja anglojęzyczna [1944] Axis Rule in Occupied Europe: Laws of Occupation, Analysis of Government, Proposals for Redress. Washington, DC: Carnegie Endowment for International Peace.

Lemkin, R. 1933 (październik). Acts Constituting a General (Transitional) Danger Considered as Offense against the Law of Nations. Dostęp: Prevent Genocide International website http://www.preventgenocide.org/lemkin/ madrid1933english.htm\#1 (20.09.2014).

Mann, T. 2008. "Niemieccy słuchacze!“ W Jabłkowska-Żychliński (red.), O kondycji Niemiec..., op. cit.: 53-54. (Oryginalna wersja niemieckojęzyczna: [1945] "Deutsche Hörer! Fünfundfünfzig Radiosendungen nach Deutschland". Wydanie 2. Stockholm; Leipzig [1975]. Dostęp: http://germanhistorydocs.ghidc.org/pdf/deu/Deutsche\%20Hörer.pdf

Midlarsky, M. I. 2010. Ludobójstwo w XX wieku. Tłum. Bartosz Wojciechowski. PWN: Warszawa (Oryginalna wersja anglojęzyczna: [2005] The Killing Trap. Genocide in the Twentieh Century. Cambridge: Cambridge University Press. 
Nolte, E. 2008. "O przeszłości, która nie chce przeminąć". W JabłkowskaŻychliński (red.), o kondycji Niemiec..., op. cit.: 372-376. (Oryginalna wersja niemieckojęzyczna: "Vergangenheit, die nicht vergehen will". Frankfurter Allegemeine Zeitung, 6.06.1986.

Nyiszli, M. 2010. Byłem asystentem doktora Mengele. Oświęcim: Oświęcim Press (oryginalna wersja węgierskojęzyczna: Orvos voltam Auschwitzbam [2001]).

Panne, J.-L. 2010. "Raphael Lemkin and Raul Hilberg: About Abort Concept". W Bieńczyk-Missala, A. \& Dębski, S. (red.), Raphael Lemkin. A Hero of Humankind, op. cit.

Rotfeld, A. D. 2010. "The Lemkin's Concept of Genocide: A New Definition for an Old Crime." W Bieńczyk-Missala \& Dębski (red.), Rafał Lemkin. A Hero of Humankind, op. cit.

Schnepf, Z. 2009. "Jak pisać o Zagładzie? Relacja z seminarium w Centrum Badań nad Zagładą Żydów IFiS PAN. Dostęp: http://www.centrumanielewicza.uw.edu.pl/kolo-relacje-schnepf2.htm (30.4.2014)

Walser, M. 2008. "Nasz Auschwitz". W Jabłkowska-Żychliński (red.), $O$ kondycji Niemiec..., op. cit.: 158-169. Wersja oryginalna: [1997] Unser Auschwitz. Werke in zwölf Bänden, Bd. 11. Hrsg. von H. Kiesel, unter Mitwirkung von F. Barsch. Frankfurt am Main: Suhrkamp: 158-172.

Zawodna, M. 2012. "O porządkowaniu poobozowego świat. Sposoby postępowania ze szczątkami ludzkimi na terenach byłego KL Auschwitz - Birkenau od momentu ostatecznej ewakuacji obozu do powstania muzeum". Zagłada Żydów. Studia i materiały. Pismo Centrum Badań nad Zagładą Żydów (pod red. D. Libionki). Warszawa: IFIS PAN: 145-165. 
Bogumił Rudawski (Poznań)

Czym jest Zagłada dla historyka?

\begin{abstract}
Abstrakt: In diesem Beitrag wird nach der Bedeutung der Judenvernichtung in den Kategorien des Genozid für einen Historiker gefragt. Um die Komplexität dieser Problematik zu zeigen, werden drei Schwerpunkte erörtert. Ausgangspunkt ist die theoretische Auffassung des Begriffes Völkermord mit besonderer Rücksicht auf die Konzeption Raphael Lemkins. Dann wird ein Problem der Historisierung des Holocaust und Bedeutung dieses Prozesses für die Geschichtsschreibung und kollektives Gedächtnis besprochen. Am Ende wird die kurze Beschreibung das Schicksal des menschlichen Körpers im Konzentrationslager als Herausforderung für eine historische Interpretation dargestellt.
\end{abstract}

Keywords: Judenvernichtung, Genozid, Historisierung des Holocaust, der menschliche Körper, Konzentrations- und Vernichtungslager, Raphael Lemkin.

Doi: 10.14746/eip.2014.2.20 